\title{
Responses to Islam in the Classroom: A Case of Muslim Girls from Minority Communities of Interpretation
}

\author{
Natasha Hakimali Merchant \\ University of Washington
}

U. S. A.

ABSTRACT: Coinciding with the rise of Islamophobia in the United States is a small but growing set of educational scholarship around the curricular impact of and response to Islamophobia. The qualitative case study discussed in this manuscript aims to contribute to this conversation by investigating how Muslim girls from minority communities of interpretation $(n=6)$ made sense of and responded to the curriculum on Islam in their Social Studies classes. The central finding describes how sample students responded to Islamophobia in the classroom by building bridges across differences. Ultimately, this study advocates a curriculum on Islam honoring complexity.

KEYWORDS: Muslim girls, curriculum on Islam, Islamophobia, teaching religion, cultural citizenship

\author{
Approaches to Teaching about Islam \\ Muslim Student Identity and Cultural Citizenship \\ Methods \\ Narrow Conceptions of Islam \\ Bridge Building as an Intervention to Islamophobia \\ Conclusion \\ References \\ Author Contact
}

After the attacks of September 11, 2001, Muslim communities across the United States learned the importance of "Muslim patriotic public relations" (Abu El Haj, 2006). Flags went up in homes and in front of Islamic Centers, as many Muslim communities and families grappled with presenting and defending their Muslim identity to friends, neighbors, and co-workers. Still today, the media coverage of Islam and Muslims reinforces the trope that Islam is a religion of extremism and violence (Friedlander, 2012). Mainstream news channels like CNN hold debates as to whether Islam promotes violence. Pundits use examples of oppressive laws in totalitarian regimes as evidence of Islam's inherent violence. Bolstered by centuries-old rhetoric demonizing Islam and Muslims (Shryock, 2010), Western policies and media have successfully framed Islam as antithetical to Western democracy. These discourses highlight the phenomenon of Islamophobia which, according to the Islamophobia Research Documentation Project (n.d.) housed at the University of California Berkeley's Center for Race and Gender, is defined by eight key notions. The notion of focus in this paper is 
that Islam is a monolith and cannot adapt to new realities. This notion is a common assumption made by many who view Islam as a frozen religion, unaffected by the passing of time or spread of geography.

The considerable pressure on Muslims to respond singularly to the "what are you question" (Sarroub, 2005, p. 127), a question ultimately gauging national loyalty, often erases difference. Islamophobia, however, is not the only limiting force curtailing the experiences of Muslims in the U.S. Intra-Muslim tensions color the ways in which many Muslims, particularly those from minority communities of interpretation, negotiate Muslim identity. Painful histories of oppression and periods of peace, still relevant today, complicate the singularity with which Muslims from minority communities of interpretation respond to the non-Muslim public in an Islamophobic social environment. Liyakatali Takim, one of the few scholars studying the contemporary Shia in the United States, elaborated on this tension by explaining a phenomenon that is now circulating around social media as Shiaphobia (Hussain, 2015). Takim unpacked this phenomenon when he explained: "Shi'is complain that their precepts and praxis are attacked more by Sunnis than by non-Muslims" (2000, p. 470). It is important to note that the question "whose Islam" is likely to arise more often for Muslims from minority communities of interpretation, rather than with dominant-identity Muslims. Dictated by the nature of privilege, those who are the 'mythical norm' don't always recognize that their experiences are not universal (Lorde, 2003).

Limited and superficial conceptions of Islam are incongruent with the diversity inherent in any culture of people (Taylor, 1994). It is within this sociopolitical context that I investigate the experiences of Muslim girls from minority communities of interpretation and ask how these girls made sense of and responded to the curriculum on Islam. The two major concepts grounding this study are curriculum and identity. Both of these concepts, discussed in the following section, are employed to better understand agentive and creative responses to shifting the narrative surrounding the questions "What is Islam?" and "Who is Muslim?"

\section{Approaches to Teaching about Islam}

World History courses, where the topic of Islam is most commonly taught, vary greatly across U.S. public schools. While a neoliberal ethos dictates international economic mobility for a professional class, it also demands a focus on American supremacy (Giroux, 2002). The conversation of how World History should be taught in schools is not simply a deliberation involving educators who decide what students ought to know to be considered educated. What gets taught in schools is informed by "the culture wars" (Zimmerman, 2002) determining the imaginary nature of "Americans" and "America." The World History curriculum taught in K-12 settings, therefore, is generally what Ross Dunn describes as an approach "particularly concerned about history and social science standards as expressions of national values and purpose" (2010, p. 
185). Dunn in his study of World History curricular models found there were four approaches used by teachers of World History (2000).

After a review of textbooks and World History standards, Dunn (2000) concluded that there were two predominant models of World History curricula. The first, which he dubbed the Western Heritage Model, strives to inculcate a sense of shared Western values, emphasizing individuality and freedom and prioritizing the contributions and narratives stemming from the West, while excluding the influence and narratives of the non-West. The second most commonly used model, the Different Cultures Model, reinforces a sense of shared Western values and adds to it by representing various cultures and their inherent traits. Although this model populates World History courses with diverse material, it reifies the assumption of distinct cultures with distinct and inherent values. The popularity of these two approaches reflects the neoliberal push toward nationalism tempered with mainstream multiculturalism, which does not adequately deconstruct notions of American supremacy and instead compounds the existing dominant narrative (Giroux, 2002). Dunn argues that although the study of anthropology has contradicted the assumption, the K-12 World History curriculum largely operates on the premise that "a civilization possesses distinctive, indeed inherent traditions that emerged largely out of the operation of mechanism internal to the particular unit" (p.187, 2010). In a curricular climate where cultures are viewed as primordially idiosyncratic, Islamophobia, with its presentation of Islam as a monolithic faith, thrives.

A position statement of the National Council of the Social Studies (2014) states that "knowledge about religions is not only a characteristic of an educated person but is necessary for effective and engaged citizenship in a diverse nation and world" (para. 1). Given the understanding that curriculum is selected and not neutral, it is important to query the NCSS statement and wonder: whose knowledge on religion? Douglass and Dunn (2003), in their article Interpreting Islam in American Schools, assisted in formulating a response to this question when they undertook a textual analysis of how Islam is presented in textbooks. They state that "there is no doubt that since the 1960s American educators have made enormous progress in reintegrating education about religion into the schools" (p. 57), while they also assert the need for more robust and meaningful coverage of Islam as a curricular topic. In their textual analysis of World History textbooks, Douglass and Dunn found that (a) students do not receive enough coverage on the topic of Islam, with the average student spending "just a few weeks in twelve years of schooling" (p. 57) covering the topic; and (b) consistent with Dunn's general findings on World History textbooks, Islam was represented as distinct, homogeneous and static (p. 58).

Another driving force in the monolithic curricular representation of Islam is the extent to which textbooks are relied upon in many secondary classrooms, particularly when teachers are unfamiliar with the topic at hand. Statistics suggest that "on average $75 \%$ to $90 \%$ of class time is spent using textbooks in public secondary schools" (Jackson, 2014, p.100). A lack of teacher knowledge might contribute to an overreliance on textbooks. Crocco offers a different 
interpretation of why many Social Studies teachers "deal with societies and cultures in a monolithic, superficial, and consensual fashion, keeping issues of difference and perspective to a minimum" (Crocco, 2005, p.564). In her article, Teaching Shabanu: The Challenges of Using World Literature in the US Social Studies Classroom (2005), she posits that Social Studies teachers "avoid multiple perspectives" because

The pressure of high-stakes testing puts a premium on coverage of content in a unified, linear, narrative fashion; the complexities of dealing with issues from multiple perspectives extends the curriculum significantly; teachers may have a felt need to maintain an 'official' posture towards the national story that does not undermine what they consider the 'patriotic' demands of social studies curriculum. (p.564)

Crocco echoes what Douglass and Dunn found through their textual analysis of textbooks. Namely, they found an overly simplistic, monolithic representation of the Muslim other, which served to bolster facile American nationalism.

The problems with curricula about World History, and Islam more specifically, are not confined to classrooms. The phenomenon of religious illiteracy is a widespread national deficit (Pew, 2010). An effort to understand the persistence of religious illiteracy in the classroom, and the ways in which curricular approaches can effectively move towards literacy, has become an area of increasing focus. Asani (2011) in his work on religious literacy highlights the two most predominant approaches to teaching about religion in the classroom: the textual approach and the devotional approach.

The textual approach to teaching about religion, Asani (2011) argues, gives primacy to a religion's scripture/s as the source for an authentic understanding about religion. The most obvious pitfall of this approach is that any given scripture, as in any literature, can only be understood through the interpretation of the reader. Therefore, trying to find authentic meaning in scripture can be a dangerous endeavor in building an academic understanding of a religion. The second approach, which Asani calls the devotional approach, is the most common approach used by teachers in classrooms. The devotional approach associates religion with the beliefs and practices of its practitioners. The pitfall of this approach is less obvious than with the textual approach. Associating a religion with beliefs and practices can lead students to understand religious expressions outside of a cultural context. Using a devotional approach often results in favoring dominant expressions of religion. Furthermore, religious rituals can be seen less as expressions of faith and more as the definition of faith itself. This was illustrated at a recent teacher workshop where I asked teachers, the somewhat unfair question, "What is Islam?" One of the teachers confidently replied, "The Five Pillars," and was met with nods of approval.

To avoid seeking an essentialist, "authentic" understanding of any religion, Moore (2007) and Asani (2011), prominent scholars of religious literacy, encourage a cultural studies approach to religion. The cultural studies approach, which is largely unutilized, is multidisciplinary in nature and engages various 
aspects of life that shape religion. A cultural studies approach is also concerned with situating knowledge claims and understanding multiple truths and experiences through a critical lens. Although teachers are uniquely shaping and innovatively delivering curricula (Apple, 1992), it is helpful to understand predominant approaches to how Islam is conceptualized, particularly given that teachers cannot be expected to have independent knowledge of Islam and will often rely on available curricular materials.

Just as critical curriculum theorists are constantly asking the question of "Whose curriculum," critical religious literacy theorists are asking the question, "Whose Islam?" The work of Douglass and Dunn (2003), Crocco (2005), and others has responded to this question by analyzing classroom texts. This study attempts to explore the question "Whose Islam?" by understanding the ways in which Muslim girls from minority communities of interpretation position their Muslim-identity in the classroom. In this way, students are viewed as contributors to the curriculum, who supplement curricular forms (like the textbook) through an embodied curriculum on Islam vis-à-vis the ways in which they perform their Muslim identities. The next section discusses how Muslim student identity interacts with curricula on Islam.

\section{Muslim Student Identity and Cultural Citizenship}

While educational research has tended to separate student identity and the Social Studies curriculum, prominent scholars of the Social Studies encourage a better understanding of the role students' identities play in the ways they make sense of the Social Studies curriculum (Barton \& McCully, 2010; Epstein, 1998, 2001, 2009; Mosborg, 2002). The limited research that has been conducted on the intersection of identity and curriculum reveals that a student's affiliations (often taught by family or community) greatly impact how they will make sense of historical curriculum (Barton \& McCully, 2010; Epstein, 1998, 2001, 2009).

A venture into Muslim students' perspectives on Islam (both historical and contemporary) would add to the burgeoning research area of curriculum and student identity, currently dominated by studies focusing on the American History curriculum. Focusing this study on the experiences of minorities within a minority allows silences and dominance in the curriculum to emerge. However, inclusion of identity-based subjects runs the risk of reifying identities as authentic and fixed. I hope to reiterate that rather than simply calling for recognition of differences, there is a deep need to acknowledge diversity, dynamism, and creativity as part of the discursive subject-making process common across the human community.

The bulk of empirical work on Muslim youth has suggested that Muslim American youth see a dissonance between their American identity and their identity as Muslim. As Abu El-Haj and Bonet (2011) have pointed out, these 
studies are predicated on the assumption that in fact there is a clash of civilizations (Huntington, 1993) and that these subjectivities (Muslim and American) are distinct in their conception and function. Abu El-Haj and Bonet (2011) instead contend that more emphasis should be placed on the cultural citizenship of Muslim youth and on the role of the school in developing Muslim youths' sense of cultural citizenship and belonging. Although the definitions of cultural citizenship are multiple, this study draws from the definition of cultural citizenship provided by Ong et al. (1996) as a "dual process of self-making and being-made" through "cultural practices and beliefs produced out of negotiating the often ambivalent and contested relations with the state and its hegemonic forms that establish the criteria of belonging within a national population and territory" (p.738). This definition of cultural citizenship highlights the creative dynamism involved in responding to oppressive and seemingly fixed narratives. The negotiation of self-making and being-made is particularly relevant in the context of this study, which examines the experiences of minorities within minorities as they essentially learn about themselves in the classroom space that "represent(s) accommodations and contestations over knowledge by differently empowered social constituencies" (Mohanty, 1997, p.16). Although the Social Studies curriculum often presents dominant and exclusive narratives (Apple, 2008; VanSledright, 2002), the classroom, populated by diverse students and perspectives, offers a unique opportunity to address the dominance of certain content, values, and ideals while at the same time introducing the social world as complex.

\section{Methods}

The data reported in this study were part of a larger dissertation project examining how teachers and students approached Islam in the classroom. The data discussed in this paper are limited to the six student participants of my dissertation study and include extended interview and questionnaire data. To investigate how Muslim girls from minority communities of interpretation made sense of and responded to curriculum on Islam, I adopted a phenomenological case study approach.

To a certain degree, all six students in the study identified with the immigrant experience, although most students were born in the United States to at least one foreign-born parent. The student participants drew their origins back to India, Pakistan, and Iraq. Being familiar, in varying degrees, with several Islamic Centers in the Northwest, I used my personal networks to recruit students. I sent out recruitment emails and private Facebook messages and relied on snowball sampling to recruit student subjects. Ultimately, students were recruited based on availability and interest. As a result of recruiting through Islamic Centers, all of the students in the sample identify themselves strongly with their religious identity and religious community. They regularly attended 
prayer services and participated in community activities like religious education classes and/or service activities organized by their religious institution.

The six case-subjects in this study were part of three bounded-groups based on three communities of interpretation (Ithnaashri ${ }^{1}$, Ismaili, ${ }^{2}$ and Ahmadiyaa $^{3}$ ). Female gender is an identity of extreme focus in the Western imagination (Mir, 2009) and impacts the ways in which Muslim bodies are responded to. Women's bodies have, in many ways, become a significant site where Muslims are determined as either safe or a potential threat to Western sensibilities. Similarly, gender performance and gendered behaviors have also been regulated by cultural gatekeepers from within the Muslim community, often landing Muslim women in the awkward position of being "safely suspended between mainstream normal" and "Muslim normal" (Mir, 2009, p. 250).

The six students, though similar in many of their identities, varied significantly in their exposure to curriculum on Islam in school. Although all of the students discussed learning about the Five Pillars of Islam, they did not report any other consistencies in what they learned about in Social Studies courses.

Table 1

Sample Student Demographic Information

\begin{tabular}{|c|c|c|c|c|}
\hline Name & Community & $\begin{array}{l}\text { Country of } \\
\text { Origin }\end{array}$ & Grade & Description of School \\
\hline Zehra & Ithnaashari & Iraq \& the U.S. & 12 & $\begin{array}{l}\text { Homeschool with co-op } \\
\text { classes }\end{array}$ \\
\hline Zaynab & Ithnaashari & India & 7 & $\begin{array}{c}\text { Public Suburban Middle } \\
\text { School }\end{array}$ \\
\hline Laila & Ahmadiyya & Pakistan & 10 & Public Urban High School \\
\hline Aiza & Ahmadiyya & Pakistan & 9 & Public Urban High School \\
\hline Aaima & Ismaili & India & 10 & $\begin{array}{c}\text { Public School } \\
\text { (International } \\
\text { Baccalaureate Curriculum) }\end{array}$ \\
\hline Tara & Ismaili & Pakistan & 10 & $\begin{array}{l}\text { Public Suburban High } \\
\text { School }\end{array}$ \\
\hline
\end{tabular}

Over the course of three months, I interviewed each of the six focal students. The interviews lasted between $1 \frac{1 / 2}{-2} 2$ hours. The student interview protocol asked students about their daily routines and their experiences with Islam in the classroom and asked them to assess how Islam was approached in their Social Studies classrooms. I transcribed each audio recording within a fiveday period of the interview. After reading through each transcription, I went 
through two rounds of coding. The initial open-coding process allowed me to read each transcript individually while keeping the research questions in mind: How do the identities of these girls influence their experiences learning about Islam in the classroom, particularly around the question, "Who is a Muslim?" Specifically, I listened for how students negotiated their knowledge and experience of Islam in the classroom setting and how students articulated their identities and beliefs about Islam in the classroom. During the second round of coding, I began to pay close attention to patterns that were emerging as complementary and distinct and, using axial coding, I further refined my codes to specify characteristics of each thematic category (Straus \& Corbin, 1990).

The questionnaire was created after all of the interviews were conducted. After completing the first two rounds of coding on all interviews, I wanted more clarity on what topics were most often covered in lessons on Islam as well as student opinions on topic selection. The information from the questionnaires helped show variation within the student cases and sub-cases, as well as a cross-comparison between student and teacher cases.

\section{Narrow Conceptions of Islam}

One of the foundational findings of this study was that the Muslim girls constantly found their own experiences of being Muslim or practicing Islam minimized and essentialized in the classroom context. Given the welldocumented record of discrimination and exclusion of Muslim youth experience in the United States, this finding was not surprising. However, in order to better understand how the curriculum might serve as an intervention to Islamophobia, describing the ways in which these students' identities were constrained is important.

Many of the girls noted that they were often correcting misperceptions of their non-Muslim peers in the classroom. Although misperceptions related to Muslim stereotypes were present, there were also misperceptions regarding who constituted a Muslim and who didn't. Research shows that most of the U.S. population claims to know little or nothing about Islam (Pew, 2010), yet many of the students' non-Muslim peers were adamant about knowing the nationality of Muslims. For example, Zaynab, who wore hijab and was therefore easily identifiable as Muslim, was asked the infamous "what are you" (Sarroub, 2005, p.127) question by a peer:

Sometimes they ask me where I'm from because there's a lot of Indian kids (in my school). I'm actually Indian. I'm pure Indian-I'm from Gujarat. They're just like 'Oh, are you Arab, are you Pakistani? Are you like Iraqi or Iranian?' I'm like, 'No, I'm Indian.' They're like, 'What? No! Indians have to be Hindu and stuff.'

Social research has documented many instances where brown communities are lumped together as 'Muslim.' Perhaps most well known are the 
incidents of hate crimes against the Sikh community who are mistaken as Muslims (Kaleem, 2013). In this case, Zaynab's peers had a strong sense of where Muslims came from and where they didn't. Ironically, Zaynab had told her peers she was from India in order to minimize confusion about her family's actual immigration story. Her family was part of the South Asian Diaspora population in East Africa. Knowing that her peers would take issue with her parents being from Africa without her being Black, she thought she was making the safer choice by claiming to be Indian. Unfortunately, she had not flattened herself sufficiently.

Aaima had a similar experience as Zaynab. It is worth noting here that Aaima is enrolled in an IB program, which prides itself on globally focused, high caliber education. Aaima recounted that she was challenged about being Muslim because of where she was born, India. She explained, "Because I think the assumption is that most Muslims are coming from Pakistan or coming from Iran and that area. When I say I'm from India, they're like, 'No, but only Hindus are in India." She talked about having an argument with a classmate who stated, "No. That's not normal for Muslims to come from India." She tried to explain that it was in fact normal. "I was like, it's very normal. I'm pretty sure." She continued on by explaining that although this conversation happened with a White friend, there were many instances in which her Hindu friends assumed she was Hindu because she was from India.

The experiences of being essentialized were not contained to racial and ethnic categories; their religious adherence was also essentialized. Zaynab noted that in a classroom discussion on the Five Pillars of Islam, she was very confused because she hadn't learned about Islam within a Five Pillar framework. Zaynab was enthusiastic to be positioned as the expert on Islam in her class, and her teacher encouraged her to contribute to classroom discussion. During the discussion on the Five Pillars of Islam, Zaynab took the opportunity to talk about five roots and ten branches, which she learned about through her religious education. It is important to note that in Zaynab's classroom context she was the only Muslim, and therefore her perspectives on Islam were easily accepted as the Muslim perspective.

In contrast, having other Muslims in the classroom, as Zehra learned, presented an added level of essentialization, which proved difficult to counter. Zehra talked about being approached by non-Muslim classmates who had heard from another Muslim student that Muslims don't celebrate Halloween. She explained, "They said, 'No, Muslims don't celebrate Halloween. It's Haraam.' (They) assume that all Muslims are the same." Zehra decided to speak up and offer her perspective to her classmates, even if her perspective would contradict the other Muslim student. She decided that she would offer her experience and a counter narrative, while making it clear that her perspective was colored by her community's interpretation. She said,

Sometimes I'll say things, but then I'll have to right away sense myself. Not only am I trying to relate to them in a way that they'll understand, but I'm also trying to figure out a way to explain it with like, "Okay, it's coming 
from my Shia beliefs," but then I'm like, "Well, but the Sunnis...they might not agree with this, so if you find a Muslim that disagrees, like, that's normal."

Zehra tried to speak in a way that related to her non-Muslim peers, but also felt a certain amount of responsibility to represent Islam in its totality and therefore felt compelled to distinguish her beliefs and practices with other Muslims.

Not every student felt they could share their dissenting experiences of Islam with their fellow students. In Laila's case, she noted that in Social Studies classes addressing Islam, "they (the teacher) taught stuff that I didn't know really about. They only teach about two sects... and that's all they teach from that view." While Laila acknowledged that her experiences and knowledge of Islam were not reflected in the curriculum, she did not feel compelled to express dissent nor did she expect the curriculum to cover the beliefs/practices of her community. Laila explained, "There's so many sects that they can't teach all of them. That's why they only teach the main ones, the majority." Considering the limited amount of time a World History curriculum can spend on teaching about Islam, Laila's argument was extremely logical. However, in their work on religious literacy, Asani (2011) and Moore (2007) suggest that teaching religion through a set of beliefs and practices runs the danger of narrowing the definition of who an adherent is. Invariably, dominant notions of the rites and rituals of Islam are taught and are assumed as universal.

Muslim subjectivity, as any other identity, is discursive and therefore the experiences of being essentialized are not one-directional. Though they were constrained by narrow conceptions of Islam and Muslims, it is important to note that these students exercised autonomy in how they performed their Muslimness. The next section discusses how the students attempted to counter an Islamophobia narrative present in the classroom. This strategy, which I call the building bridges strategy, was used by all students in the sample.

\section{Bridge Building as an Intervention to Islamophobia}

In order to frame this finding, it is important to acknowledge the affective experiences of the sample students in class when they discussed Islam. To better understand the affective response to curriculum on Islam, each of the students was asked how they felt when Islam was being discussed in their Social Studies classrooms. Students were prompted to choose from the following responses: nervous/anxious, excited, indifferent or other with a write-in option. All but one of the students chose nervous/anxious as their response. Aaima, who differed in her affective experience, chose excited as her response. The affective experiences are important to note, particularly because they illustrate that despite tensions around the topic of Islam, students found ways to respond to essentialized notions of Muslims and Islam. 
Even though the students performed their Muslim identities in a variety of ways, with some taking on classroom roles as "the expert" and others remaining silent, they all believed that focusing on religious commonalities with their peers and teachers was the most effective path to educating against Islamophobia. In each of the interviews, students spoke about seeking commonalities between Islam and other religions, particularly Christianity, as a means to quelling stereotypes.

Aaima, the only participant who considered her peers well-informed about Muslim rituals, felt that Muslim stereotypes were still rampant among her peers. However, Aaima asserted that stereotypes would successfully be quelled if there was a common focus on humanistic ethics, rather than rites and rituals. She said, "The people around me, I feel like they don't need to ... when it comes to discussions about Islam, they don't need to be told about religious practices. I just want to discuss ethics with them and things that we hold similar." Aaima explained that connecting over shared ethics and principles allows for deeper connections and friendships. Zehra and Zaynab reiterated this in their interviews.

Zehra, for example, spoke about how an acquaintance from the homeschool system became a close friend as a result of exchanging information about their religions. She recounted,

[She] had just finished her home school component of her history book she was reading, and they had touched on Islam but she was reading it independently and doing the work with her mom and was asking me, like, 'So I was reading that Muslims, like, do this and they fast and they do this', and asking me about Prophet Mohammed, and Allah and what that means...We had a really deep conversation about it, and after the conversation, just looked at each other and we felt even closer than we were before because we knew a little bit more about one another because I also was getting to ask her questions about Christianity and we were explaining the misconceptions and stuff about our religions.

Like Aaima, Zehra saw friendship as an effective method to deconstructing misperceptions about Muslims and Islam.

In addition to focusing on building personal relationships, as in Zehra or Aaima's cases, students also sought to build connections across religion through intervening in the official classroom curriculum. Aaiza spoke about how using a guest speaker, rather than relying on a textbook, would make Islam more relatable to non-Muslim students. She stated, "Maybe they should actually bring in real-life examples. When they have public speakers it makes a difference. It's a person. It's not just like you're learning...you can empathize, sympathize with them so you can understand it more." Aaiza's statement, "It's a person" beautifully illustrates the power the students see in bridge building. Viewing the Muslim-other as a dynamic person with complexities allows for a deeper connection, which Zehra and Aaima both sought through their interactions with peers. 
Zaynab, along with the other students, desired that her non-Muslim peers view Muslims as similar to themselves. Like Aaiza, Zaynab wanted her Christian counterparts to humanize Muslims, and therefore she spoke about the importance of learning about the diversity within Muslim communities. In speaking about why she thought sectarian differences should be taught in lessons on Islam, Zaynab explained:

Because then they can relate to us, especially if they're a different religion... they can be like 'oh yeah, they have different practices even within their one religion. Their main belief system is the same, but they do things a little differently, just like even though we are Catholics, the Christians that aren't, are still Christian, but they don't do all the same things that we do.'

Just as in Zaynab's case, all of the students, in varying ways, argued for building bridges as a method to humanize Muslims and Islam.

Although the students who participated in this study had different ways of approaching bridge building, at the heart of their approach was a foundational strategy: the strategy of humanizing the Muslim and Islam. Aaima, for example, focused on a humanistic approach to build commonality, whereas Zaynab focused on highlighting diversity within traditions in order to highlight commonalities across religions. Perhaps the most compelling example of bridge building through humanization was exemplified in Zehra's example. Zehra described an experience of becoming closer to a non-Muslim peer and, through friendship, sharing religious beliefs and histories. When Zehra recalled what it felt like after sharing religious histories and perspectives with her friend, she noted, "We just looked at each other and we felt even closer than we were before because we knew a little bit more about one another." This again illustrated the power Zehra recognized in a mutual humanization. The bridge-building strategy involved sharing personal accounts and experiences of faith. This strategy, as an intervention to Islamophobia in the classroom, raises two important questions for future research: "What does it mean to be educated about Islam?" and "What are the most effective curricular approaches to aid this education?"

\section{Conclusion}

This study aimed to learn from the practices of young people, while acknowledging that students cannot be consistently relied upon to provide texture, depth, and a critical lens on Islam. For this reason, implications of this study focus on curricular approaches to teaching about Islam in the Social Studies classroom. While students aimed to humanize Muslims through bridge building, it is important to remember that students were operating within an Islamophobic sociopolitical climate. This point is significant because it sheds a critical light on the act of bridge building as an agentive strategy aimed at shifting the narrative. When students were seeking to build bridges, it was less about a 
mutual effort of two sides striving to understand each other; instead, their examples revealed that bridge building was more about their non-Muslim peers fulfilling their curiosities about Islam. Although the students' bridge building could be seen as part of an act of cultural citizenship, in which they used these strategies to "forge membership and actively participate in their societies" (Abu El Haj \& Bonet, 2011), it remains that the students were constrained by the invisible reference point of dominant normative discourses. Decentering the reference point and broadening concepts of the norm would require a much larger decolonial curriculum project. This undertaking would include not only a redesign of substantive knowledge (Schwab, 1978; Wineburg, 1997), but indeed it would involve a reconceptualization of epistemological approaches (Wineburg, 1997).

How then, can a curriculum offer an approach grounded in multiple perspectives and complexity? According to the work of Asani and Moore, the predominant approaches to teaching about Islam follow a singular narrative and focus on beliefs and rituals. Instead, Asani and Moore promote a cultural studies approach to teaching about religion. However, within the current constraints of K12 Social Studies, the cultural studies approach faces several practical challenges. As Laila pointed out, "There's so many sects that they can't teach all of them. That's why they only teach the main ones, the majority." Given the challenge of teaching Islam amid several other topics in a shrinking discipline (Grant, 2008), how can religion be taught such that it is inclusive of several experiences, yet substantial in its depth? Although the answer to this question is beyond the scope of this study, the participants' experiences reveal important considerations for a re-conceptualized curriculum on Islam.

A curriculum that allows complex and varied representations benefits the entire student population by enhancing knowledge and critical thinking. For students who identify as minorities within a minority, as in the case with the students in this study, a robust curriculum, as Rosaldo explained, can provide space for embodying polyglot citizenship (1994). He elaborated, "Curriculum debates bring up questions of "Who's the we?" in a plural society and offer hopes of bringing about cultural decolonization by recognizing the value of cultural life in the United State" (p.410). Future research on a curriculum on Islam to support the notion of cultural citizenship, one that centers genuine inclusion and belonging, could ease the rigid definitions and divides that constrict the fullness and complexity of lived experiences.

\section{References}

Abu El-Haj, T. R. (2006). Race, politics, and Arab American youth: Shifting frameworks for conceptualizing educational equity. Educational Policy, 20(1), 13-34. 
Abu El-Haj, T. R., \& Bonet, S. W. (2011). Educating Muslim American youth in a post-9/11 era: A critical review of policy and practice. The High School Journal, 95, 46-55.

Apple, M. W. (1992). The text and cultural politics. Educational Researcher, 21(7), 4-11.

Apple, M. W. (2008). Curriculum planning: Content, form, and the politics of accountability. In M. F. Connelly, M. F. He, \& J. Phillion (Eds.), The Sage handbook of curriculum and instruction (pp. 25-44). Los Angeles, CA: Sage.

Asani, A. S. (2011). Enhancing religious literacy in a liberal arts education through the study of Islam and Muslim societies. The Harvard Sampler: Liberal Education for the Twenty-first Century, 1.

Barton, K., \& McCully, A. (2010). "You can form your own point of view": Internally persuasive discourse in Northern Ireland students' encounters with history. The Teachers College Record, 112(1), 142-181.

Crocco, M. S. (2005). Teaching Shabanu: The challenges of using world literature in the US social studies classroom. Journal of Curriculum Studies, 37(5), 561-582.

Dunn, R. (2010). The two world histories. In Parker, W. (Ed.), Social studies today: Research and practice. New York, NY: Routledge.

Douglass, S. L., \& Dunn., R. E. (2003). Interpreting Islam in American schools. The ANNALS of the American Academy of Political and Social Science, 588, 52-72.

Epstein, T. (1998). Deconstructing differences in African-American and European-American adolescents' perspectives on U.S. History. Curriculum Inquiry, 28, 397-423.

Epstein, T. (2001). Racial identity and young people's perspectives on social education. Theory into practice, 40(1), 42-47.

Epstein, T. (2009). Interpreting national history: Race, identity and pedagogy in classrooms and communities. New York, NY: Routledge.

Friedlander, K. (2012, December 27). A look back at media coverage of Islam and Islamic law in 2012. Huffington Post. Retrieved from http://www.huffingtonpost.com/krystina-friedlander/a-look-back-at-mediacoverage-of-islam-and-islamic-law-in-2012_b_2346943.html

Giroux, H. (2002). Neoliberalism, corporate culture, and the promise of higher education: The university as a democratic public sphere. Harvard Educational Review, 72(4), 425-464.

Grant, S. G. (Ed.). (2008). Measuring history: Case of state-level testing across the United States. Greenwich, CT: Information Age.

Huntington, S. P. (1993). The clash of civilizations? Foreign affairs, 72(3), 22-49. 
Hussain, Z. (2015). How I tackled 'Shiaphobia' at school. Retrieved from https://themuslimvibe.com/muslim-lifestyle-matters/education/how-itackled-shiaphobia-at-school

Jackson, L. (2014). Muslims and Islam in US education: Reconsidering multiculturalism. New York, NY: Routledge.

Kaleem, J. (2013, June 19). School prayer 50 years later: What do Americans believe? The Huffington Post. Retrieved from http://www.huffingtonpost. com/2013/06/19/school-prayer_n_3461479.html

Lalani, A. R. (2000). Early Shi'i thought: The teachings of Imam Muhammad AlBaqir. London, UK: I. B. Tauris.

Lorde, A. (2003). The master's tools will never dismantle the master's house. In R. Lewis \& S. Mills (Eds.) Feminist postcolonial theory: A reader (pp. 2528). New York, NY: Routledge.

Merriam, S. B. (2009). Qualitative Research: A guide to design and implementation. San Francisco, CA: Jossey-Bass.

Mir, S. (2009). Not too "college-like," not too normal: American Muslim undergraduate women's fendered discourses. Anthropology \& Education Quarterly, 40(3), 237-256.

Mohanty, C. T. (1997). Preface: Dangerous territories, territorial power and education. In L. Eyre \& L. Roman (Eds.), Dangerous Territories: Struggles for Difference and Equality in Education (pp. ix - xvii). New York, NY: Routledge.

Moore, D. (2007). Overcoming religious illiteracy: A cultural studies approach to the study of religion in secondary education. New York, NY: Palgrave Macmillan.

Mosborg, S. (2002). Speaking of history: How adolescents use their knowledge of history in reading the daily news. Cognition and Instruction, 20, 323358.

Nanji, A. (Ed.). (1996). The Muslim almanac: A reference work on the history, faith, culture, and peoples of Islam. Detroit, MI: Gale Group.

NCSS Position Statements. (2014). Study about religions in the Social Studies curriculum. Retrieved from http://www.socialstudies.org/positions/ study_about_religions

Ong, A., Dominguez, V. R., Friedman, J., Schiller, N. G., Stolcke, V., Wu, D. Y., \& Ying, H. (1996). Cultural citizenship as subject-making: immigrants negotiate racial and cultural boundaries in the United States [and comments and reply]. Current anthropology, 737-762.

Pew Research Center on Religion and Public Life. (2010). U.S. religious knowledge survey: Who knows what about religion. Retrieved from http://www. pewforum.org/2010/09/28/u-s-religious-knowledge-survey-whoknows-what-about-religion/ 
Rosaldo, R. (1994). Cultural citizenship and educational democracy. Cultural anthropology, 9(3), 402-411.

Sarroub, L. K. (2005). All American Yemeni girls - Being Muslim in a public school. Philadelphia, PA: University of Pennsylvania Press.

Schwab, J. J. (1978). Education and the structure of the disciplines. In I. Westbury \& N. J. Wilhof (Eds.), Science, curriculum, and liberation: Selective essays (pp. 229-272). Chicago, IL: The University of Chicago Press.

Shryock, A. (2010). Islamophobia/Islamophilia: Beyond the politics of enemy and friend. Bloomington, IN: Indiana University Press.

Takim, L. (2000). Foreign influences on American Shi'ism. The Muslim World, 90(3/4), 459-478.

Taylor, C. (1994). The politics of recognition. In A. Herble, D. P. Pennee, \& J. R. Struthers (Eds.), New contexts of Canadian criticism (pp. 98-131). Ontario, Canada: Broadview Press.

Valentine, S. R. (2014). Prophecy after the Prophet, albeit lesser prophets? The Ahmadiyya Jama'at in Pakistan. Contemporary Islam, 8(2), 99-113.

VanSledright, B. (2002). In search of America's past: Learning to read history in elementary school. New York, NY: Teachers College Press.

Wineburg, S. (1997). Beyond "breadth and depth": Subject matter knowledge and assessment. Theory into Practice, 36(4), 255-261.

\section{Notes}

1. Ithnaasharis are the largest community of Shias in the world. "Twelver Shiism has been the official religion of Iran since 1501" (Nanji, 1996).

2. Ismailis are the second largest community of Shias in the world. The Ismailis were eventually fractured many times. "Currently, the bulk of the Ismailis of the world, who belong to the majority Nizari branch, recognize as their fortyninth present and living imam, His Highness Karim Aga Khan" (Nanji, 1996).

3. Ahmadiyyas are arguably the most persecuted minority sect within Islam. The community was founded in 1889 in the Punjab region of India. The founder of the Ahmadiyya movement, Mirza Ghulan Ahmad (1835-1908) claimed prophet-hood, which prompted many Muslim scholars to decree a fatwa of heresy against Ahmad. They adhere to many of the beliefs and practices of other Sunni Muslims but have controversial interpretations around succession, jihad, and Jesus (Valentine, 2014). 


\section{Author Contact}

Natasha Hakimali Merchant: merch786@uw.edu University of Washington

1410 NE Campus PKWY

Seattle WA, 98195-2840

U. S. A. 